\title{
Analisis Keputusan Transfer Pricing Berdasarkan Pajak, Tunneling dan Exchange Rate
}

\author{
${ }^{1 *}$ Hani Sri Mulyani, ${ }^{2}$ Endah Prihartini, ${ }^{3}$ Dadang Sudirno \\ ${ }^{1,2,3}$ Fakultas Ekonomika dan Bisnis, Universitas Majalengka, Indonesia \\ *Email korenpondensi: hanisrimulyani@unma.ac.id
}

\begin{abstract}
Tax has two points of view, for the government tax is a source of state revenue that has the largest contribution, but for tax companies is a burden that must be paid. Often companies do tax planning strategies so that the tax burden that must be borne by the company becomes smaller. Companies usually exploit loopholes from the use of accounting methods allowed by accounting and taxation rules. Transfer Pricing is one of the ways companies take to reduce the tax burden. This study aims to determine and obtain empirical evidence about the effect of tax, tunneling and exchange rates on transfer pricing decisions both partially and simultaneously on manufacturing companies listed on the Indonesia Stock Exchange (IDX) for the 2013-2017 period. The research method used is descriptive and verification analysis method. The population in this study were 144 manufacturing companies listed on the Indonesia Stock Exchange in the period 2013-2017. Sampling using a purposive sampling method and obtained a sample of 20 companies. The results of this study indicate that partially significant positive effect on transfer pricing decisions, tunneling does not significantly influence the transfer pricing and exchange rate decisions do not significantly influence the transfer pricing decision, but simultaneously the results of this study indicate that taxes, tunneling and exchange rates affect significant to the transfer pricing decision.
\end{abstract}

Keywords : exchange rate, transfer pricing, tunneling.

Saran sitasi: Mulyani, H. S., Prihatini, E., \& Sudirno, D. (2020). Analisis Keputusan Transfer Pricing Berdasarkan Pajak, Tunneling dan Exchange Rate. Jurnal Akuntansi dan Pajak, 20(2), 166-176. doi: http://dx.doi.org/10.29040/jap.v20i2.756

DOI: http://dx.doi.org/10.29040/jap.v20i2.756

\section{Pendahuluan}

Transfer pricing adalah suatu kebijakan perusahaan dalam menentukan harga transfer suatu transaksi baik itu barang, jasa, harta tak berwujud ataupun transaksi finansial yang dilakukan oleh perusahaan. Intra-company transfer pricing merupakan konsep harga transfer antar divisi dalam satu perusahaan sedangkan inter-company transfer pricing merupakan konsep harga transfer antara dua perusahaan yang mempunyai hubungan istimewa. Transaksinya dengan menggunakan harga transfer bisa dilakukanan oleh dua perusahan atau lebih yang berelasi dalam satu negara (domestic transfer pricing), maupun dengan negara yang berbeda (international transfer pricing) (Setiawan, 2014)

Berdasarkan penelitian tim UNTC PBB yang diketuai Silvain Plasschaert sebagaimana dinyatakan kembali oleh Gunadi (1999) dalam Sutedi (2013), disebutkan bahwa terdapat beberapa motivasi yang melatarbelakangi perusahaan dalam melakukan transfer pricing di Indonesia antara lain: (1) pengurangan objek pajak, terutama pajak penghasilan; (2) pelonggaran pengaruh pembatasan kepemilikan luar negeri; (3) penurunan pengaruh deperesiasi rupiah; (3) menguatkan tuntutan kenaikan harga atau proteksi terhadap saingan impor; (4) mempertahankan sikap low profile tanpa mempedulikan tingkat keuntungan usaha; (5) 


\section{Jurnal Akuntansi dan Pajak, 20(02), 2019, 172}

mengamankan perusahaan dari tuntutan atas imbalan atau kesejahteraan karyawan dan kepedulian lingkungan; (6) memperkecil akibat pembatasan dan risiko bisnis di luar negeri. Adapun menurut Anthony dan Govindarajan (2004) dalam Sutedi (2013) mengemukakan bahwa terdapat tiga permasalahan khusus yang dihadapi korporasi multinasional yaitu: (1) perbedaan budaya (cultural differences); (2) transfer pricing; (3) nilai tukar mata uang (exchange rate). Penelitian ini hanya mengkaji motivasi pajak, tunneling dan exchange rate dalam pengambilan keputusan transfer pricing. Ini disebabkan karena hal tersebut merupakan permasalahan khusus yang lazim dihadapi oleh perusahaan multinasional akibat perbedaan regulasi, ekonomi, sosial, politik dan budaya yang berlaku pada setiap negara.

Seiring dengan perkembangan zaman, perusahaan multinasional telah memanfaatkan transfer pricing sebagai upaya perencanaan pajak perusahaan untuk menghindari pajak dengan cara meminimalkan beban pajak yang harus ditanggung perusahaan. Menurut Lingga (2012) transfer pricing biasanya dilakukan dengan cara memperbesar harga beli dan memperkecil harga jual antara perusahaan dalam satu grup/rekanan atau antar perusahaan yang memiliki hubungan istimewa dan mentransfer laba yang diperoleh kepada rekanan perusahaan yang berkedudukan di luar negri yang menerapkan tarif pajak yang rendah.

Besar kecilnya beban pajak yang harus dibayarkan merupakan salah satu faktor yang dapat memicu tindakan transfer pricing yang dilakukan oleh perusahan. Dalam pandangan pajak atau fiskal, transfer pricing sangat berpotensi menyebabkan risiko berkurang atau hilangnya potensi penerimaan pajak suatu negara karena perusahaan multinasional cenderung menggeser kewajiban perpajakannya dari negara-negara yang memiliki tarif pajak yang tinggi (high tax countries) ke negara-negara yang menerapkan tarif pajak rendah (low tax countries). Secara umum Kebijakan fiscal atau perpajakan harus memperhatikan dua hal mendasar agar koreksi pajak terhadap dugaan transfer pricing mendapat justifikasi yang kuat, yaitu: afiliasi (associated enterprises) atau hubungan istimewa (special relationship) dan kewajaran atau arm's length principle (Bakti, 2002 dalam Yuniasih et al., 2012).

Selain motivasi pajak, transfer pricing juga dipicu oleh tindakan pengalihan asset yang dikenal dengan istilah Tunneling. Tunneling merupakan kondisi untuk menggambarkan pengambilan aset suatu pemegang saham non-pengendali di Republik Ceko melalui pengalihan aset dan keuntungan demi kepentingan pemegang saham pengendali (Guing dan Farahmita, 2011 dalam Noviastika et al., 2016). Struktur kepemilikan mencerminkan jenis konflik keagenan yang terjadi. Untuk perusahaan di Asia kebanyakan memiliki struktur kepemilikan yang terkonsentrasi, termasuk di Indonesia. Struktur kepemilikan terkonsentrasi ini menimbulkan potensi bagi pemegang saham pengendali untuk terlibat jauh dalam pengelolaan perusahaan (Mispiyanti, 2015). Kepemilikan saham yang terkonsentrasi menimbulkan hak kendali dan memberikan kesempatan bagi pemegang saham pengendali untuk melakukan ekspropriasi terhadap hak pemegang saham non-pengendali melalui kegiatan tunneling. Menurut Johnson dalam Wafiroh dan Hapsari (2015) tunneling merupakan aktivitas pengalihan aset dan keuntungan keluar perusahaan untuk kepentingan pemegang saham pengendali perusahaan tersebut.

Nilai tukar juga dapat mempengaruhi praktek transfer pricing. Perusahaan multinasional mempunyai transaksi antar negara dalam jumlah yang besar. Arus kas perusahaan tersebut didenominasikan dalam beberapa mata uang relatif kepada nilai dolar akan berbeda seiring dengan perbedaan waktu. Exchange rate yang berbeda-beda inilah yang nantinya akan mempengaruhi laba perusahaan secara keseluruhan. Oleh karena itu perubahan nilai tukar dapat dimanfaatkan oleh perusahan multinasional untuk meningkatkan profitabilitas perusahaan melalui kegiatan transfer pricing. Profitabilitas sangat penting bagi investor dan dijadikan sebagai salah satu indikator penilaian dalam pengambilan keputusan investasi pada perusahaan.

Di Indonesia transaksi antar anggota perusahaan multinasional tidak luput dari rekayasa transfer pricing, terutama oleh wajib pajak penanaman modal asing (PMA) dan cabang perusahaan asing di Indonesia yang termasuk dalam kategori bentuk usaha tetap (BUT). Sebagian besar perusahaan tersebut bergerak di bidang manufaktur dan mempunyai kaitan internal yang cukup substansial dengan induk perusahaan atau afiliasinya di mancanegara. Perusahaan di Indonesia terutama dimanfaatkan sebagai manufaktur barang madya (intermediate goods) atau bahan mentah (raw materials) mereka. Produk hasil pabrik Indonesia tersebut dipasarkan ke pasar lokal atau diekspor ke negara ketiga (Gunadi, 1999 dalam Santoso, 2004). 
Berdasarkan informasi yang diperoleh dari berita online m.liputan6.com pada tanggal 28 Maret 2016 memuat bahwa Direktur Penyuluhan, Pelayanan, dan Hubungan Masyarakat DJP Kemenkeu, Mekar Satria Utama menyatakan bahwa sebanyak 2.000 perusahaan asing terindikasi mengemplang pajak selama 10 tahun karena alasan merugi terus-menerus dan salah satu penyebabnya yaitu perusahaan tersebut merupakan perusahaan afiliasi yang induk perusahaannya berada di luar negeri sehingga sangat rawan terjadi proses transfer pricing. DJP mempertanyakan pembayaran royalti yang tetap disetorkan anak usahanya di Indonesia kepada induk perusahaanya. "Ada perbedaan tarif antara kita dan negara partner sehingga mereka menjual dengan harga murah. Mereka membeli bahan baku dengan harga lebih tinggi. Jadi perusahaan-perusahaan yang ada di Indonesia mengalami rugi, tapi perusahaan di luar negeri untung," jelas Mekar.

Penelitian yang dilakukan oleh Marfuah dan Azizah (2014) menyimpulkan bahwa pajak berpengaruh negatif signifikan terhadap keputusan transfer pricing perusahaan, tunneling incentive berpengaruh positif terhadap keputusan transfer pricing perusahaan dan exchange rate berpengaruh positif tetapi tidak signifikan terhadap keputusan transfer pricing perusahaan. Sedangkan penelitian yang dilakukan Mispiyanti (2015) menyimpulkan bahwa pajak dan mekanisme bonus tidak berpengaruh signifikan terhadap keputusan transfer pricing, tunneling incentive berpengaruh signifikan terhadap keputusan transfer pricing. Adapun penelitian yang dilakukan Andraeni (2017) menyimpulkan bahwa exchange rate berpengaruh terhadap keputusan perusahaan melakukan transfer pricing, tunneling incentive berpengaruh terhadap keputusan perusahaan melakukan transfer pricing dan mekanisme bonus tidak berpengaruh terhadap keputusan perusahan melakukan transfer pricing.

\section{Metode Penelitian}

\section{Metode yang Digunakan}

Metode penelitian yang digunakan adalah metode kuantitatif. Jenis Penelitian dalam penelitian ini adalah jenis penelitian survei dengan metode analisis statistik deskriptif dan verifikatif.

\section{Definisi Operasional Variabel}

Variabel Independen (Bebas)

Variabel independen dalam penelitian ini adalah:

\section{Pajak $\left(\mathbf{X}_{1}\right)$}

Pajak dalam penelitian ini diproksikan dengan Current Effective Tax Rate (current ETR). Current ETR dihitung dari beban pajak penghasilan kini (current tax expense) dibagi dengan laba sebelum pajak perusahaan (pre-tax income). Current ETR dirumuskan sebagai berikut:

\section{Current $\mathrm{ETR}=\underline{\text { current tax expense }}$ pre-tax income}

Sumber: Hanlon dan Heitzman (2010) dalam Tandean (2015).

\section{Tunneling}

Tunneling diukur dengan persentase kepemilikan saham mayoritas oleh perusahaan asing sebesar $20 \%$ atau lebih dari total saham yang beredar yang disebut sebagai pemegang saham pengendali. Adapun rumus tunneling adalah sebagai berikut:

Tunneling= Jumlah Kepemilikan Saham Terbesar Jumlah Saham Beredar

Sumber: Andraeni (2017).

\section{Exchange Rate (Nilai Tukar/Kurs)}

Exchange rate pada penelitian ini diukur dari keuntungan atau kerugian transaksi perusahaan yang menggunakan mata uang asing. Exchange rate dihitung dari laba atau rugi selisih kurs dibagi dengan laba atau rugi sebelum pajak. Exchange rate dihitung dengan rumus berikut ini:

Exchange rate $=$ Laba rugi selisih kurs

$$
\text { Laba rugi sebelum pajak }
$$

Sumber: Marfuah dan Azizah (2014)

\section{Variabel Dependen (Terikat)}

Variabel dependen (terikat) dalam penelitian ini adalah transfer pricing. Transfer pricing adalah suatu kebijakan perusahaan dalam menentukan harga atas penyerahan barang, jasa, harta tak berwujud ataupun transaksi finansial yang dilakukan oleh perusahaan antar divisi ataupun antar pihak yang mempunyai hubungan istimewa.

Transfer pricing dalam penelitian ini diukur dengan menggunakan variabel dummy yang dihitung dengan pendekatan dikotomi, yaitu dengan melihat keberadaan penjualan kepada pihak yang mempunyai hubungan istimewa. Perusahaan yang melakukan penjualan kepada pihak yang mempunyai hubungan istimewa diberi nilai 1 dan yang tidak diberi 0 . 


\section{Jurnal Akuntansi dan Pajak, 20(02), 2019, 174}

\section{Populasi dan Sampel}

Populasi dalam penelitian ini adalah perusahaan manufaktur yang terdaftar di Bursa Efek Indonesia periode 2013-2017 yang berjumlah 144 perusahaan. Teknik penentuan sampel yang akan digunakan dalam penelitian ini adalah teknik purposive sampling. Berikut adalah kriteria perusahaan yang dijadikan sampel dalam penelitian ini: Perusahaan manufaktur yang terdaftar di Bursa Efek Indonesia dari tahun 2013 sampai dengan tahun 2017; Perusahaan yang konsisten terdaftar di Bursa Efek Indonesia periode 2013-2017; Perusahaan yang dikendalikan oleh perusahaan asing dengan persentase kepemilikan 20\% atau lebih (PSAK No.15); Perusahaan tidak mengalami kerugian selama periode pengamatan. Hal ini karena perusahaan yang mengalami kerugian tidak memiliki kewajiban perpajakan di tingkat perusahaan sehingga motivasi pajak menjadi tidak relevan; Perusahaan yang menyajikan data lengkap sesuai dengan informasi yang dibutuhkan dalam penelitian ini. Berdasarkan kriteria tersebut diperoleh sampel sebanyak 20 perusahaan dengan periode pengamatan 5 tahun sehingga diperoleh data sampel sebanyak 100 data sampel

\section{Rancangan Analisis Data dan Uji Hipotesis}

Analisis data dalam penelitian ini adalah menggunakan metode deskripftif dan metode verifikatif dengan regresi logistic dan uji hipotesis

\section{Menilai Analisis Koefisien Regresi}

Analisis koefisien regresi dilakukan untuk menguji seberapa jauh variabel independen mempunyai pengaruh terhadap kemungkinan perusahaan melakukan transfer pricing, dilakukan dengan memperhatikan beberapa hal berikut ini:

1) Tigkat signifikan $(\alpha)$ yang digunakan sebesar $5 \%$ $(0,05)$.

2) Kriteria penerimaan dan penolakan hipotesis didasarkan pada significant p-value (probabilitas value).

a. Jika p-value (significant) $\alpha>(5 \%)$, maka hipotesis alternatif ditolak. Artinya bahwa variabel independen tidak berpengaruh terhadap variabel dependen.

b. Jika p-value (significant) $\alpha<(5 \%)$, maka hipotesis alternatif diterima. Artinya bahwa variabel independen berpengaruh terhadap variabel dependen.
Sedangkan model persamaan analisis regresi logistik yang digunakan adalah sebagai berikut:

$$
\operatorname{Ln}(\mathrm{Y} / 1-\mathrm{Y})=\beta_{0}+\beta_{1} \mathrm{X}_{1}+\beta_{2} \mathrm{X}_{2}+\beta_{3} \mathrm{X}_{3}+\varepsilon
$$

Keterangan:

$$
\begin{array}{lll}
\operatorname{Ln}(\mathrm{Y} / 1-\mathrm{Y}) & = & \text { Logaritma probabilitas perusahaan } \\
& & \text { yang melakukan transfer pricing } \\
& =\text { Konstanta } \\
\beta_{0} & =\text { Pajak } \\
\mathrm{X}_{1} & =\text { Tunneling } \\
\mathrm{X}_{2} & =\text { Exchange rate } \\
\mathrm{X}_{3} & =\text { Koefisien regresi } \\
\beta_{1}-\beta 2-\beta 3 & =\text { Error term } \\
\varepsilon &
\end{array}
$$

\section{Menguji Signifikansi Model}

Pengujian secara keseluruhan dilakukan untuk menguji seberapa jauh semua variabel independen (pajak, tunneling dan exchange rate) mempunyai pengaruh terhadap kemungkinan perusahaan melakukan transfer pricing. Pengujiannya dapat menggunakan tabel "Omnimbus Test of Model Coefficient" untuk melihat hasil pengujian secara simultan pengaruh variabel bebas dengan melihat hasil dari signifikansinya diperoleh nilai sig.model, dengan ketentuan:

a. Jika p-value (significant) $\alpha>(0,05)$, maka hipotesis alternatif ditolak. Artinya bahwa variabel independen secara bersama-sama tidak berpengaruh terhadap variabel dependen.

b. Jika $p$-value (significant) $\alpha<(0,05)$, maka hipotesis alternatif diterima. Artinya bahwa variabel independen secara bersama-sama berpengaruh terhadap variabel dependen.

\section{Hasil dan Pembahasan}

\subsection{Hasil penelitian}

Bagian ini menyajikan hasil penelitian. Hasil penelitian dapat dilengkapi dengan tabel, grafik (gambar), dan/atau bagan [Times New Roman, 11, normal].

\section{Menilai Kelayakan Model Regresi}

Dalam menilai kelayakan model regresi dapat dilakukan dengan melihat tabel berikut ini:

\section{Tabel 1}

Hosmer and Lemeshow Test

\begin{tabular}{lccrr}
\hline Step & Chi-square & df & & \multicolumn{1}{c}{ Sig. } \\
\hline 1 & 6,727 & & 8 &, 566 \\
\hline
\end{tabular}

Sumber: data diolah tahun 2018

Berdasarkan tabel 1 diatas dapat dilihat bahwa nilai statistik Hosmer and Lemeshow Goodness of Fit sebesar 6,727 dengan signifikansi sebesar 0,566 yang nilainya lebih besar dari 0,05 atau signifikansi $>0,05$ maka hipotesis nol tidak dapat ditolak $\left(\mathrm{H}_{0}\right.$ diterima dan $\mathrm{H}_{1}$ ditolak). Hal ini berarti model regresi yang 


\section{Jurnal Akuntansi dan Pajak, 20(02), 2019, 175}

dipergunakan dalam penelitian ini layak dipakai untuk analisis selanjutnya, karena tidak ada perbedaan yang nyata antara klasifikasi yang diprediksi dengan klasifikasi yang diamati. Sehingga dapat dikatakan bahwa model yang dihipotesiskan fit dengan data karena mampu memprediksi nilai observasinya atau dapat dikatakan bahwa model dapat diterima karena sesuai dengan data observasinya.

\section{Menilai Keseluruhan Model (Overall Model Fit)}

Dalam menilai keseluruhan model (overall model fit) dapat dilakukan dengan beberapa cara, diantaranya sebagai berikut:

\section{1) Chi-Square $\left(\mathrm{X}^{2}\right)$}

Tes statistik Chi Square $\left(\mathrm{X}^{2}\right)$ digunakan berdasarkan pada fungsi likelihood pada estimasi model regresi, dilakukan dengan menggunakan pengujian terhadap nilai -2 Log Likelihood. Pengujian ini dapat dilakukan dengan membandingkan nilai -2 Log Likelihood awal (hasil block number 0) dengan nilai -2 Log Likelihood akhir (hasil block number 1). Apabila terjadi penurunan, maka model tersebut menunjukkan model regresi yang baik.

Tabel 2

Overall Model Fit

\begin{tabular}{cc}
\hline Iteration & -2 Log Likelihood \\
\hline Step 0 & 60,508 \\
Step 1 & 50,882 \\
\hline
\end{tabular}

Sumber: data diolah tahun 2018

Tabel 2 menunjukkan angka pada -2 Log Likelihood block number $=0$ dan -2 Log Likelihood block number $=1$. Pada tabel tersebut terlihat bahwa angka awal -2 Log Likelihood block number $=0$ adalah 60,508 sedangkan angka 2 Log Likelihood block number $=1$ adalah 50,882. Penurunan nilai -2 Log Likelihood ini menunjukkan model regresi yang baik atau dengan kata lain model yang dihipotesiskan fit dengan data.

\section{2) Cox and Snell's $R$ Square dan Nagelkereke's $R$ square}

Untuk mengetahui besarnya variasi prediksi dari variabel pajak, tunneling dan exchange rate terhadap keputusan transfer pricing dapat dilihat dari nilai $R$ Square. Adapun hasil pengujiannya sebagai berikut:

Tabel 3

Hasil Uji Cox \& Snell R Square dan Nagelkerke $R$ Square

Model Summary

\begin{tabular}{cccc}
\hline Step & -2 Log & Cox \& Snell R Nagelkerke R \\
& likelihood & Square & Square \\
\hline
\end{tabular}

$1 \quad 50,882^{a}$

, 092

,202

.a. Estimation terminated at iteration number 6 because parameter estimates changed by less than ,001

Pada tabel 3 diperoleh nilai Cox \& Snell $R$ Square sebesar 0,092 dan Nagelkerke $R$ Square sebesar 0,202. Hasil ini berarti bahwa 20,2\% variasi transfer pricing dapat diprediksi atau dijelaskan oleh variabilitas variabel pajak, tunneling dan exchange rate. Sementara sisanya $79,8 \%$ dapat dijelaskan oleh variabel lain yang tidak digunakan pada penelitian ini.

\section{3) Tabel Klasifikasi $2 \times 2$}

Untuk mengetahui kekuatan prediksi dan mendapatkan tingkat ketepatan dari model yang digunakan untuk memprediksi kemungkinan terjadinya transfer pricing oleh perusahaan dapat dilihat pada tabel berikut ini:

Tabel 4

Tabel Klasifikasi 2x2

Classification Table ${ }^{\mathrm{a}}$

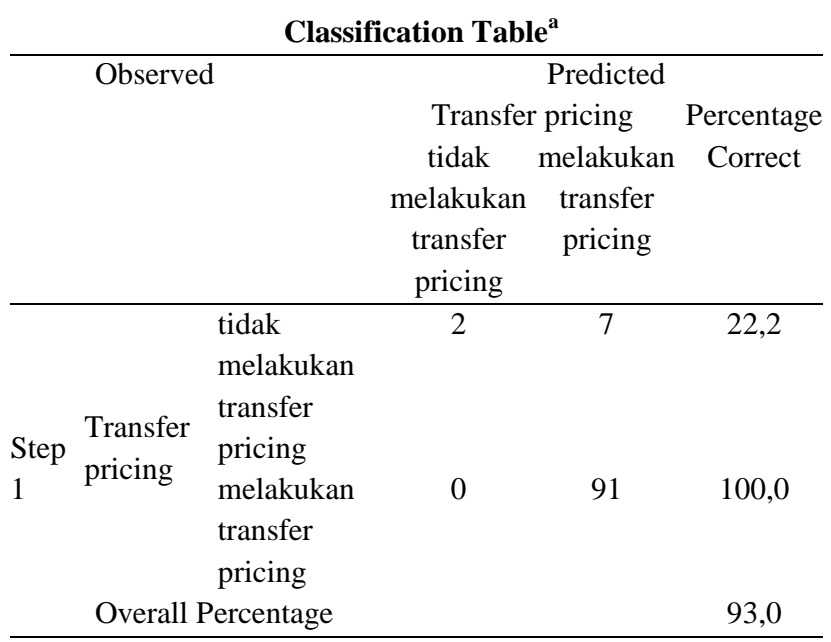

a. The cut value is ,500

Sumber: diolah tahun 2018

Tabel di atas, menunjukkan bahwa nilai overall percentage sebesar 93,0. Sehingga dapat disimpulkan bahwa model regresi logistik dalam penelitian ini dapat digunakan untuk memprediksi keputusan transfer pricing perusahaan dengan tingkat keakuratan sebesar 93,0\% dengan batas nilai atau cut value yang dihasilkan 0,500 .

Berdasarkan tabel 4 diatas menunjukkan tingkat keakurasian 93,0\% menjelaskan bahwa dari 9 perusahaan, yang diprediksi dalam kondisi tidak melakukan transfer pricing terdapat 2 perusahaan dan yang melakukan transfer pricing terdapat 7 perusahaan. Selain itu dari 91 perusahaan, yang diprediksi melakukan transfer pricing terdapat 91 perusahaan dan yang tidak melakukan transfer pricing terdapat 0 perusahaan.

Uji Hipotesis 


\section{Jurnal Akuntansi dan Pajak, 20(02), 2019, 176}

$\mathrm{H}_{1}$ : Pengaruh pajak terhadap keputusan transfer pricing

Berdasarkan tabel 4 pajak memiliki nilai signifikansi sebesar 0,019 di bawah tingkat signifikansi $0,05(5 \%)$. Sehingga dapat disimpulkan bahwa Ho ditolak dan $\mathrm{H}_{1}$ diterima. Hal ini berarti pajak berpengaruh signifikan terhadap keputusan transfer pricing, dengan demikian $\mathrm{H}_{1}$ dapat dibuktikan kebenarannya.

$\mathrm{H}_{2}$ :'Pengaruh tunneling terhadap keputusan transfer pricing

Berdasarkan tabel 4 tunneling memiliki nilai signifikansi sebesar 0,148 di atas tingkat signifikansi $0,05(5 \%)$. Sehingga dapat disimpulkan bahwa Ho diterima dan $\mathrm{H}_{2}$ ditolak. Hal ini berarti tunneling tidak berpengaruh signifikan terhadap keputusan transfer pricing, dengan demikian $\mathrm{H}_{2}$ tidak dapat dibuktikan kebenarannya.

$\mathrm{H}_{3}$ : Pengaruh exchange rate terhadap keputusan transfer pricing

Berdasarkan tabel 4 texchange rate memiliki nilai signifikansi sebesar 0,241 di atas tingkat signifikansi $0,05(5 \%)$. Sehingga dapat disimpulkan bahwa Ho diterima dan $\mathrm{H}_{3}$ ditolak. Hal ini berarti exchange rate tidak berpengaruh signifikan terhadap keputusan transfer pricing, dengan demikian $\mathrm{H}_{3}$ tidak dapat dibuktikan kebenarannya.

$\mathrm{H}_{4}$ : Pengaruh pajak, tunneling dan exchange rate terhadap keputusan transfer pricing

Berdasarkan tabel 4 hasil pengujian Omnibus Test of Model Coefficient diperoleh nilai signifikansi 0,016 di bawah tingkat siginfikansi 0,05 (5\%). Sehingga dapat disimpulkan bahwa Ho ditolak dan $\mathrm{H}_{4}$ diterima. Hal ini berarti pajak, tunneling dan exchange rate secara bersama-sama berpengaruh signifikan terhadap keputusan transfer pricing sehingga $\mathrm{H}_{4}$ dapat dibuktikan kebenarannya.

\subsection{Pembahasan}

\section{Pengaruh Pajak Terhadap Keputusan Transfer Pricing}

Berdasarkan hasil penelitian dengan menggunakan regresi logistik menunjukkan bahwa nilai koefisien regresi variabel pajak sebesar 14,324 dan bertanda positif, artinya jika beban pajak perusahaan semakin tinggi maka kemungkinan terjadinya keputusan transfer pricing akan semakin tinggi. Sebaliknya jika beban pajak perusahaan semakin rendah maka kemungkinan terjadinya transfer pricing akan semakin rendah.

Berdasarkan hasil pengujian hipotesis diketahui bahwa variabel pajak berpengaruh secara signifikan terhadap keputusan transfer pricing. Hal ini dapat dibuktikan dengan tingkat signifikansi pajak sebesar 0,019 lebih kecil dari tingkat signifikansi 0,05 (5\%). Dengan demikian penelitian ini menolak $\mathrm{H}_{0}$ dan menerima $\mathrm{H}_{1}$ yang menyatakan bahwa pajak berpengaruh terhadap keputusan transfer pricing.

Penelitian ini konsisten dengan penelitian Yuniasih, et al. $(2012)^{38}$ yang menyatakan bahwa pajak berpengaruh positif pada keputusan transfer pricing. Namun penelitian ini tidak konsisten dengan penelitian Marfuah dan Azizah (2013) ${ }^{14}$, Sari dan Mubarok $(2017)^{26}$ yang menyatakan bahwa pajak berpengaruh negatif signifikan terhadap keputusan transfer pricing perusahaan dan dan penelitian Mispiyanti $(2015)^{17}$ juga menyatakan bahwa pajak tidak berpengaruh signifikan terhadap keputusan transfer pricing.

Hasil penelitian ini sesuai dengan teori yang menyatakan bahwa praktik transfer pricing sering dimanfaatkan oleh perusahaan-perusahaan multinasional untuk meminimalkan jumlah pajak yang harus dibayar. Praktik transfer pricing dapat dilakukan dengan cara memperbesar harga beli atau memperkecil harga jual antara perusahaan dalam satu grup dan mentransfer laba yang diperoleh kepada grup yang berkedudukan di negara yang menerapkan tarif pajak yang rendah.

Berdasarkan hasil penelitian beban pajak perusahaan yang semakin besar mendorong perusahaan untuk melakukan keputusan transfer pricing dengan harapan dapat menekan beban tersebut. Selanjutnya ketika beban pajak perusahaan sudah bisa ditekan serendah mungkin yang semakin kecil perusaahaan tidak cenderung tidak melakukan keputusan transfer pricing.

Hasil penelitian ini mengindikasikan bahwa pajak berpengaruh positif signifikan terhadap keputusan transfer pricing. Hal ini disebabkan karena perusahaan manufaktur periode 2013-2017 yang memiliki beban pajak yang rendah. Pajak yang rendah mengindikasikan adanya pengalihan kewajiban perpajakan ke perusahaan yang memiliki hubungan istimewa di negara lain yang tarif pajaknya lebih rendah.

\section{Pengaruh Tunneling Terhadap Keputusan Transfer Pricing}

Berdasarkan hasil penelitian dengan menggunakan regresi logistik menunjukkan bahwa nilai koefisien regresi variabel tunneling sebesar 3,253 dan bertanda negatif, artinya jika kepemilikan saham pengendali asing semakin besar maka 


\section{Jurnal Akuntansi dan Pajak, 20(02), 2019, 177}

kemungkinan terjadinya transfer pricing akan semakin kecil. Sebaliknya jika kepemilikan saham pengendali asing semakin kecil maka kemungkinan terjadinya transfer pricing akan semakin besar.

Berdasarkan hasil pengujian hipotesis diketahui bahwa variabel tunneling tidak berpengaruh secara signifikan terhadap keputusan transfer pricing. Hal ini dapat dibuktikan dengan tingkat signifikansi tunneling sebesar 0,148 lebih besar dari tingkat signifikansi $0,05(5 \%)$. Dengan demikian penelitian ini menerima $\mathrm{H}_{0}$ dan menolak $\mathrm{H}_{2}$ yang menyatakan bahwa tunneling tidak berpengaruh terhadap keputusan transfer pricing.

Penelitian ini konsisten dengan penelitian Melani (2016) ${ }^{16}$ yang menyatakan bahwa tunneling incentive tidak berpengaruh terhadap keputusan melakukan transfer pricing. Namun penelitian ini tidak konsisten dengan penelitian Yuniasih, et al. $(2012)^{38}$, Marfuah dan Azizah (2013) $)^{14}$, Mispiyanti $(2015)^{17}$, Refgia (2017) ${ }^{24}$ dan Andraeni (2017) ${ }^{1}$ yang menyatakan bahwa tunneling incentive berpengaruh signifikan terhadap keputusan transfer pricing perusahaan.

Hasil penelitian ini tidak mendukung teori yang menyatakan semakin besar persentase kepemilikan yang dimiliki pemegang saham, semakin besar pula kendali yang dimiliki pemegang saham dalam menentukan berbagai keputusan perusahaan termasuk keputusan transfer pricing. Namun hasil penelitian ini sesuai dengan argumen PIE (positif incentive effect) yang menyatakan bahwa pemegang saham pengendali tidak akan melakukan ekspropriasi terhadap pemegang saham minoritas karena pemegang saham pengendali merupakan pihak yang paling merasakan dampak negatif dari penurunan nilai perusahaan atas tindakan ekspropriasi tersebut. Dengan argumen PIE, kemampuan pemegang saham pengendali untuk mengendalikan manajemen tidak ditujukan untuk kepentingan pribadi melainkan justru untuk menunjukkan kepada pemegang saham minoritas bahwa tidak terjadi ekspropriasi dalam perusahaan (Siregar, 2008) ${ }^{29}$.

Berdasarkan hasil penelitian kepemilikan saham pengendali yang tinggi cenderung tidak melakukan transfer pricing dengan tujuan menjaga citra perusahaan sehingga menarik minat investor agar menginvestasikan dananya pada perusahaan. Sebaliknya ketika kepemilikan saham pengendali rendah artinya ada investor yang sudah menginvestasikan dananya kepada perusahaan dan fokus pemegang saham pengendali tidak lagi menarik minat investor akan tetapi untuk memaksimalkan keuntungan pribadi mereka sendiri sehingga akan mendorong perusahaan untuk melakukan transfer pricing sebagai tindakan ekspropriasi terhadap pemegang saham minoritas.

Tidak berpengaruhnya tunneling terhadap keputusan transfer pricing disebabkan karena perusahaan manufaktur periode 2013-2017 memiliki rata-rata nilai tunneling yang tinggi. Hal tersebut menunjukkan struktur kepemilikan perusahaan terkonsentrasi hanya pada sedikit pemilik. Ketika kepemilikan dan pembuat keputusan perusahaan terkonsentrasi hanya pada segelintir pihak tertentu yaitu pihak asing maka pemegang saham pengendali cenderung lebih bertindak risk averse (menghindari risiko). Pemegang saham pengendali tidak memanfaatkan transfer pricing dalam rangka ekspropriasi terhadap pemegang saham minoritas karena berisiko menimbulkan konflik yang berdampak pada penurunan nilai perusahaan dan penilaian buruk investor sehingga investor enggan untuk menginvestasikan dananya pada perusahaan. Selain itu mekanisme pengawasan yang efektif baik secara internal seperti adanya dewan komisaris independen maupun secara eksternal seperti adanya auditor sehingga akan membatasi pemegang saham pengendali melakukan tindakan ekspropriasi seperti transfer pricing dalam rangka memaksimalkan kesejahteraan pribadi. Dengan demikian besarnya kepemilikan saham pengendali belum tentu dapat menentukan berbagai keputusan perusahaan termasuk keputusan transfer pricing.

\section{Pengaruh Exchange Rate Terhadap Keputusan Transfer Pricing}

Berdasarkan hasil penelitian dengan menggunakan regresi logistik menunjukkan bahwa nilai koefisien regresi variabel exchange rate sebesar 3,045 dan bertanda positif, artinya jika laba akibat selisih kurs yang diperoleh perusahaan semakin tinggi maka terjadinya transfer pricing akan semakin tinggi. Sebaliknya jika laba akibat selisih kurs yang diperoleh perusahaan semakin rendah maka kemungkinan terjadinya transfer pricing akan semakin rendah.

Berdasarkan hasil pengujian hipotesis diketahui bahwa variabel exchange rate tidak berpengaruh secara signifikan terhadap keputusan transfer pricing. Hal ini dapat dibuktikan dengan tingkat signifikansi exchange rate sebesar 0,241 lebih besar dari tingkat signifikansi 0,05 (5\%). Dengan demikian penelitian ini menerima $\mathrm{H}_{0}$ dan menolak $\mathrm{H}_{3}$ yang 


\section{Jurnal Akuntansi dan Pajak, 20(02), 2019, 178}

menyatakan bahwa exchange rate tidak berpengaruh terhadap keputusan transfer pricing.

Penelitian ini konsisten dengan penelitian Marfuah dan Azizah (2013) ${ }^{14}$ yang menyatakan bahwa exchange rate berpengaruh positif tetapi tidak signifikan terhadap keputusan transfer pricing perusahaan. Namun penelitian ini tidak konsisten dengan penelitian Andraeni (2017) ${ }^{1}$ yang menyatakan bahwa exchange rate berpengaruh terhadap keputusan perusahaan melakukan transfer pricing.

Secara teoritis perubahan nilai tukar merupakan peluang bagi perusahaan untuk mengendalikan risiko dari keuntungan maupun kerugian transaksi, perusahaan dapat menggunakan transfer pricing dengan cara merekayasa harga produk yang ditransfer kepada perusahaan yang mempunyai hubungan istimewa. Namun menurut Ardiyanti $(2017)^{2}$ melemahnya mata uang domestik membuat perusahaan merugi dalam transaksi dengan pihak asing yang menggunakan kurs, seperti misalnya untuk mendapatkan sejumlah bahan baku dengan jumlah yang sama pada harga dollar yang sama memerlukan jumlah rupiah yang lebih banyak akibat dari pelemahan nilai rupiah terhadap dollar. Melalui alasan tersebut, perusahaan tidak melihat perubahan nilai tukar untuk mengambil keputusan transfer pricing.

Berdasarkan hasil penelitian ketika nilai tukar pada perusahaan tinggi maka akan mendorong perusahaan untuk melakukan keputusan transfer pricing dengan merekayasa harga yang bertujuan mengurangi laba sehingga pembayaran pajak menjadi berkurang. Sebaliknya ketika nilai tukar pada perusahaan rendah maka perusahaan cenderung tidak melakukan keputusan transfer pricing karena dengan nilai tukar yang rendah perusahaan tidak perlu lagi mengurangi laba. Walaupun demikian nilai tukar tidak berpengaruh terhadap keputusan transfer pricing perusahaan.

Tidak berpengaruhnya exchange rate terhadap keputusan transfer pricing disebabkan pada perusahaan manufaktur periode 2013-2017 banyak terdapat kerugian akibat selisih kurs atas kegiatan operasi perusahaan dan dapat dilihat pada tabel 4.2 hasil analisis deskriptif menunjukkan nilai rata-rata exchange rate bernilai negatif. Dengan demikian dapat disimpulkan bahwa exchange rate bukan merupakan suatu pertimbangan khusus bagi manajemen dalam pengambilan keputusan transfer pricing karena perusahaan memandang bahwa adanya perubahan nilai tukar tidak memberikan keuntungan potensial bagi perusahaan.

Pengaruh Pajak, Tunneling dan Exchange Rate Terhadap Keputusan Transfer Pricing

Berdasarkan hasil pengujian yang telah dilakukan dalam penelitian ini dapat dijelaskan bahwa pajak, tunneling dan exchange rate secara bersama-sama berpengaruh secara signifikan terhadap keputusan transfer pricing pada perusahaan manufaktur yang terdaftar di BEI periode 2013-2017. Hal ini diketahui dari tabel 4.10 bahwa pajak, tunneling dan exchange rate berpengaruh terhadap keputusan transfer pricing sebesar 10,380 dengan signifikansi 0,016 berada dibawah tingkat signifikasi $0,05(5 \%)$. Dengan demikian penelitian ini menolak $\mathrm{H}_{0}$ dan menerima $\mathrm{H}_{4}$ yang menyatakan bahwa pajak, tunneling dan exchange rate secara bersama-sama berpengaruh terhadap keputusan transfer pricing. Atau minimal ada satu variabel bebas yang berpengaruh signifikan dan untuk mengetahui variabel mana saja yang masuk ke dalam model dapat dilihat pada uji parsial.

Hasil penelitian ini mendukung teori yang dikemukakan oleh Anthony dan Govindarajan (2011) dalam Marfuah dan Azizah (2014) ${ }^{14}$ bahwa pertimbangan penting suatu perusahan multinasional untuk melakukan keputusan transfer pricing diantaranya adalah pajak, tunneling incentive dan exchange rate. Hasil penelitian ini juga menunjukan bahwa pajak, tunneling dan exchange rate merupakan faktor-faktor penting yang dijadikan pertimbangan oleh manajemen dalam pengambilan keputusan transfer pricing. Adanya perbedaan tarif pajak di setiap negara dan pemegang saham pengendali memiliki pengendalian dalam menentukan kebijakan perusahaan serta didukung dengan adanya fluktuasi nilai tukar akan menimbulkan peluang bagi perusahaan sehingga memotivasi perusahaan untuk melakukan keputusan transfer pricing. Transfer pricing adalah mekanisme penetapan harga atas transaksi penyediaan barang atau penyerahan jasa oleh pihak-pihak yang memiliki hubungan istimewa. Namun dalam praktiknya perusahaan melakukan rekayasa harga transfer sebagai upaya meminimalkan biaya-biaya termasuk minimalisasi pembayaran pajak perusahaaan. Bagi perusahaan multinasional transfer pricing dipercaya menjadi salah satu strategi yang efektif untuk memenangkan persaingan dalam memperebutkan sumber-sumber daya yang terbatas. 


\section{Kesimpulan}

Berdasarkan hasil penelitian dan pembahasan mengenai pengaruh pajak, tunneling dan exchange rate terhadap keputusan transfer pricing pada perusahaan manufaktur yang terdaftar di BEI periode 2013-2017, maka dapat diambil kesimpulan sebagai berikut:

1. Pajak berpengaruh positif signifikan terhadap keputusan transfer pricing. Hal ini dikarenakan beban pajak yang semakin besar mendorong perusahaan untuk menekan beban pajak tersebut dengan melakukan keputusan transfer pricing yaitu mengalihkan kewajiban perpajakan ke perusahaan yang memiliki hubungan istimewa di negara lain yang tarif pajaknya lebih rendah.

2. Tunneling tidak berpengaruh signifikan terhadap keputusan transfer pricing. Hal ini dikarenakan perusahaan menerapkan mekanisme pengawasan efektif dan adanya kepemilikan saham pengendali asing yang tinggi yang cenderung akan bertindak menghindari risiko dengan tidak memanfaatkan transfer pricing dalam rangka ekspropriasi terhadap pemegang saham minoritas karena berisiko menimbulkan konflik yang berdampak pada penurunan nilai perusahaan dan penilaian buruk investor.

3. Exchange rate tidak berpengaruh signifikan terhadap keputusan transfer pricing. Hal ini dikarenakan rata-rata perusahaan manufaktur mengalami kerugian akibat selisih kurs atas kegiatan operasi perusahaan sehingga menunjukkan exchange rate bukan merupakan suatu pertimbangan khusus bagi manajemen dalam pengambilan keputusan transfer pricing karena perusahaan memandang bahwa adanya perubahan nilai tukar tidak memberikan keuntungan potensial bagi perusahaan.

4. Pajak, tunneling dan exchange rate secara simultan berpengaruh terhadap keputusan transfer pricing perusahaan. Hal ini menunjukkan bahwa pajak, tunneling dan exchange rate merupakan faktor-faktor penting yang dijadikan pertimbangan oleh manajemen dalam pengambilan keputusan transfer pricing. Transfer pricing adalah mekanisme penetapan harga atas transaksi penyediaan barang atau penyerahan jasa oleh pihak-pihak yang memiliki hubungan istimewa. Namun dalam praktiknya perusahaan melakukan rekayasa harga transfer sebagai upaya meminimalkan biaya-biaya sehingga bagi perusaahaan multinasional transfer
, 20(02), 2019, 179

pricing dipercaya menjadi salah satu strategi yang efektif untuk memenangkan persaingan dalam memperebutkan sumber-sumber daya yang terbatas.

\section{Daftar Pustaka}

Andraeni, S.S. (2017). Pengaruh Exchange Rate, Tunneling Incentive, dan Mekanisme Bonus Terhadap Keputusan Perusahaan Melakukan Transfer Pricing Studi pada Perusahaan Manufaktur yang Terdaftar di Bursa Efek Indonesia Periode 2013-2015. Skripsi. Universitas Islam Negeri Syarif Hidayatullah. Jakarta.

Ardiyanti, D. (2017). Pengaruh Mekanisme Bonus, Tax Minimization, Exchange Rate dan Multinationality Terhadap Keputusan Transfer Pricing. Skripsi. Universitas Muhammadiyah Yogyakarta.

Brundy, E. (2014). Pengaruh Mekanisme Pengawasan Terhadap Aktivitas Tunneling. Skripsi. Universitas Atma Jaya. Yogyakarta.

Eko Pranata. (2014). Perbandingan Metode Regresi Logistik dengan Analisis Diskriminan. Universitas Sumatera Utara.

Ety Rochaety. (2007). Kamus Istilah Ekonomi. PT Bumi Aksara. Jakarta.

Hanafi, M.M. (2003). Manajemen Keuangan Internasional. Edisi 2003/2004. Cetakan Pertama. BPFE-Yogyakarta.

Handayani, D. dan T. Arfan. (2014). Pengaruh Transaksi Perusahaan Afiliasi Terhadap Tarif Pajak Efektif. Jurnal Akuntansi Keuangan dan Bisnis Vol. 7, 11-19.

Hasibuan, D.H.M. dan Nopryannus. (2013). Analisis Selisih Kurs dan Pengaruhnya Terhadap Laporan Laba Rugi Perusahaan. Jurnal Ilmiah Akuntansi Kesatuan (JIAKES) Vol. 1, No. 2, pg 151-160. ISSN 2337-7852.

Ghozali, Imam (2013). Aplikasi Analisis Multivariate dengan Program SPSS. Universitas Diponegoro. Semarang.

Keputusan Direksi PT Bursa Efek Jakarta Nomor Kep-308/BEJ/07-2004. Penghapusan Pencatatan (Delisting) dan Pencatatan Kembali (Relisting) Saham di Bursa. 19 Juli 2004. PT Bursa Efek Jakarta. Jakarta.

Kiswanto, N. (2014). Pengaruh Pajak, Kepemilikan Asing, dan Ukuran Perusahaan Terhadap Transfer Pricing pada Perusahaan Manufaktur di BEI Tahun 2010-2013. Skripsi. Universitas Atma Jaya. Yogyakarta. 


\section{Jurnal Akuntansi dan Pajak, 20(02), 2019, 180}

Lingga, I.S. (2012). Aspek Perpajakan dalam Transfer Pricing dan Problematika Praktik Penghindaran Pajak. Zenit: Jurnal Ilmiah Universitas Kristen Maranatha Vol. 1, No. 3, Desember 2012.

Madura, J. (1995). International Financial Management. West Publishing Company. Terjemahan E. Salim. 2000. Manajemen Keuangan Internasional. Edisi 4. Jilid 1. Erlangga. Jakarta.

Marfuah dan A.P.N. Azizah. (2014). Pengaruh Pajak, Tunneling Incentive dan Exchange Rate pada Keputusan Transfer Pricing Perusahaan. Jurnal Akuntansi dan Auditing Indonesia (JAAI) Vol. 18, No. 2, Desember 2014: hal 156-165.

Mardiasmo. (2016). Perpajakan. CV Andi Offset. Yogyakarta.

Melani, T. (2016). Pengaruh Tax Minimization, Mekanisme Bonus, Tunneling Incentive dan Ukuran Perusahaan Terhadap Keputusan Melakukan Transfer Pricing. Skripsi. Universitas Islam Negeri Syarif Hidayatullah. Jakarta.

Mispiyanti. (2015). Pengaruh Pajak, Tunneling Incentive dan Mekanisme Bonus Terhadap Keputusan Transfer Pricing. Jurnal Akuntansi dan Investasi Vol. 16, No. 1, Januari 2015.

Mutamimah. (2009). Tunneling atau Value Added dalam Strategi Merger dan Akuisisi di Indonesia. Jurnal Manajemen dan Teori Terapan Tahun 2, No. 2, Agustus 2009.

Noviastika F, D., Y. Mayowan, dan S. Karjo. 2016. Pengaruh Pajak, Tunneling Incentive dan Good Corporate Governance (GCG) Terhadap Indikasi Melakukan Transfer Pricing pada Perusahaan Manufaktur yang Terdaftar di Bursa Efek Indonesia (Studi pada Bursa Efek Indonesia yang Berkaitan dengan Perusahaan Asing). Jurnal Perpajakan (JEJAK) Vol. 8, No. 1.

Nurhayati, I.D. (2013). Evaluasi atas Perlakuan Perpajakan terhadap Transaksi Transfer Pricing pada Perusahaan Multinasional di Indonesia. Jurnal Manajemen dan Akuntansi Vol. 2, No. 1, April 2013.

Pernyataan Standar Akuntansi Keuangan No. 7 (Revisi 2014). Pengungkapan Pihak-Pihak Berelasi. Dewan Standar Akuntansi Keuangan. Ikatan Akuntansi Indonesia. Jakarta.
Pernyataan Standar Akuntansi Keuangan No. 7 (Revisi 2015). Pengungkapan Pihak-Pihak Berelasi. Dewan Standar Akuntansi Keuangan. Ikatan Akuntansi Indonesia. Jakarta.

Pernyataan Standar Akuntansi Keuangan No. 15 (Revisi 2014). Investasi Pada Entitas Asosiasi dan Ventura Bersama. Dewan Standar Akuntansi Keuangan. Ikatan Akuntansi Keuangan Indonesia. Jakarta.

Refgia, T. (2017). Pengaruh Pajak, Mekanisme Bonus, Ukuran Perusahaan, Kepemilikan Asing, dan Tunneling Incentive Terhadap Transfer Pricing (Perusahaan Sektor Industri Dasar dan Kimia Yang Listing di BEI Tahun 2011-2014). Jurnal Online Mahasiswa Fakultas Ekonomi (JOM) Fekon Vol. 4, No. 1, Februari 2017.

Santoso, I. (2004). Advance Pricing Agreement dan Problematika Transfer Pricing dari Perspektif Perpajakan Indonesia. Jurnal Akuntansi dan Keuangan Vol. 6, No. 2, Nopember 2004: hal: 123-139.

Sari, E.P. dan A. Mubarok. (2017). Pengaruh Profitabilitas, Pajak dan Debt Covenant Terhadap Transfer Pricing (Studi Empiris Perusahaan Manufaktur Terdaftar di BEI Tahun 2012-2016). Seminar Nasional. Universitas Pamulang, 13 Desember 2017. ISSN: 977 2599343004.

Sari, R.C. dan A. Taman. (2011). Pengembangan Model Prediksi Tunneling: Bukti Empiris pada Transaksi Pihak Berelasi Perusahaan Publik di Indonesia. Artikel Penelitian Hibah Bersaing. Universitas Yogyakarta. November 2011.

Setiawan, H. (2014). Transfer Pricing dan Risikonya Terhadap Penerimaan Negara. Jurnal.

Siregar, B. (2008). Ekspropriasi Pemegang Saham Minoritas dalam Struktur Kepemilikan Ultimat. Jurnal.

Suandy, E. (2008). Perencanaan Pajak. Edisi 4. Salemba Empat. Jakarta.

Sugiyono. (2016). Metode Penelitian Manajemen. Cetakan ke-5. CV Alfabeta. Bandung.

Sutedi, A. 2013. Hukum Pajak. Cetakan kedua. Sinar Grafika. Jakarta

Tandean, V.A. (2015). Pengaruh Good Corporate Governance dan Ukuran Perusahaan Terhadap Tax Avoidance. Prosiding Seminar Nasional Multi Disiplin \& Call For Paper Unisbank (SENDI_U). ISBN: 978-979-3649-81-8. 


\section{Jurnal Akuntansi dan Pajak, 20(02), 2019, 181}

Undang-Undang Republik Indonesia Nomor 16 Tahun 2009. Ketentuan Umum dan Tata Cara Perpajakan. 25 Maret 2009. Lembaran Negara Republik Indonesia Tahun 2009 Nomor 62. Jakarta.

Undang-Undang Republik Indonesia Nomor 36 Tahun 2008. Pajak Penghasilan. 23 September 2008. Lembaran Negara Republik Indonesia Tahun 2008 Nomor 133. Jakarta.

Wafiroh, N.L. dan N.N. Hapsari. (2015). Pajak, Tunneling Incentive dan Mekanisme Bonus pada Keputusan Transfer Pricing. El-Muhasaba: Jurnal Akuntansi Fakultas Ekonomi UIN Maulana Malik Ibrahim Malang Vol. 6, No. 2, Juli 2015.
Yuliati, S.H. dan H. Prasetyo. (2005). Dasar-dasar Manajemen Keuangan Internasional. Edisi 2. C.V. Andi Offset. Yogyakarta.

Yuniasih, N.W., N.K. Rasmini, dan M.D. Wirakusuma. (2012). Pengaruh Pajak dan Tunneling Incentive pada Keputusan Transfer Pricing Perusahaan Manufaktur yang Listing di Bursa Efek Indonesia. Simposium Nasional Akuntansi.

Zain, M. (2008). Manajemen Perpajakan. Edisi 3. Cetakan Kedua. Salemba Empat. Jakarta.

www.idx.co.id

www.liputan 6.com

www.sahamok.com 